\title{
Genotoxicity, anti-melanoma and antioxidant activities of Hymenaea courbaril L. seed extract
}

\section{KAMILLE D. SPERA ${ }^{1}$, PATRÍCIA A. FIGUEIREDO ${ }^{1}$, PAMELA C.E SANTOS ${ }^{1}$, FERNANDO C. BARBOSA $^{1}$, CAIO P. ALVES ${ }^{1}$, ANNE LÍGIA DOKKEDAL ${ }^{2}$, LUIZ LEONARDO SALDANHA ${ }^{2}$, LUCIANA P. SILVA ${ }^{3}$, CARLOS ROGÉRIO FIGUEIREDO ${ }^{4}$, PAULO CESAR FERREIRA ${ }^{1}$ and REGILDO M.G. DA SILVA ${ }^{1}$}

\author{
${ }^{1}$ Universidade Estadual Paulista/UNESP, Faculdade de Ciências e Letras de Assis, Departamento de Biotecnologia, \\ Laboratório de Fitoterápicos e Produtos Naturais, Av. Dom Antônio, 2100, 19806-900 Assis, SP, Brazil \\ ${ }^{2}$ Departamento de Ciências Biológicas, Faculdade de Ciências, Universidade Estadual Paulista/UNESP, Av. Eng. \\ Luís Edmundo Carrijo Coube, 2085, Núcleo Residencial Presidente Geisel, 17033-360 Bauru, SP, Brazil \\ ${ }^{3}$ Fundação Educacional do Município de Assis/FEMA, Av. Getulio Vargas, 1200, Vila Nova Santana,19807-130 Assis, SP, Brazil \\ ${ }^{4}$ Departamento de Microbiologia, Imunologia e Parasitologia, Divisão de Biologia Celular, Unidade de Oncologia Experimental/ \\ UNONEX, Universidade Federal de São Paulo/UNIFESP, Rua Botucatu, 740, Vila Clementino, 04023-062 São Paulo, SP, Brazil
}

Manuscript received on May 6, 2018; accepted for publication on October 26, 2018

How to cite: SPERA KD ET AL. 2019. Genotoxicity, anti-melanoma and antioxidant activities of Hymenaea courbaril L. seed extract. An Acad Bras Cienc 91: e20180446. DOI 10.1590/0001-3765201920180446.

\begin{abstract}
Hymenaea courbaril has been used to treat different diseases, although its properties are yet to be scientifically validated. The objective of this study was to determine the cytotoxicity, genotoxicity, antigenotoxicity and antioxidant potentials of hydroethanolic extract from $H$. courbaril seeds. Therefore, for the cytotoxicity test an anti-melanoma assay was performed in B16F10 strain cells. The genotoxicity and antigenotoxicity was evaluated in bone marrow cells (Permit number: 002/2010) of mice, the antioxidant activity was determined by the DPPH test and the total flavonoid content was also determined. The hydroethanolic extract showed antigenotoxic effect and antioxidant activity. It was verified that total flavonoid content was $442.25 \pm 18.03 \mathrm{mg}$ RE/g dry extract. HPLC-PAD chromatogram revealed presence of flavones as majority compound in evaluated extract. The results allowed us to also infer that the hydroethanolic extract from seeds shows cytotoxic activity against B16F10 melanoma cells line and it has dose-and-time-dependency.
\end{abstract}

Key words: B16F10 melanoma cells, micronucleus test, chromosomal aberration, DPPH radical scavenging, HPLC-DAD.

\section{INTRODUCTION}

Cancer is one of the major causes of death worldwide (Assaf et al. 2013). Development of cancer in humans is a multifactorial process (Choudhari et al. 2014). It can rise as a result of genetic alterations

Correspondence to: Regildo Márcio Gonçalves da Silva

E-mail: regildos@yahoo.com.br

ORCid: https://orcid.org/0000-0002-0300-0247 which are mediated by endogenous and exogenous factors. Inactivation of tumor suppressor genes, inactivation of genes responsible for apoptosis, activation of oncogenes, DNA damage due to lack of repair or incomplete repair are some of the factors related to carcinogenesis (Kryston et al. 2011).

The side effects presented by current chemotherapeutics and synthetic drug resistant cancer cells have increased the demand for new 
anticancer agent's development. In this context, the plants have been highlighted. They have been the basis of traditional medicine for thousands of years and now have been widely studied for the anticancer activity (Krishnaiah et al. 2011). Several compounds isolated from plants are still not used as therapeutical drugs, but they have potential for the development of anticancer agents. Phenolic compounds such as flavonoids have been highlighted by presenting a range of pharmacological activities such as antioxidant, antimutagenic, anti-inflammatory and anticancer activity.

Hymenaea courbaril (Fabacea, Caesalpinioideae) is commonly known in Brazil as"Jatobá"(Veggi et al. 2014). Apart from its ecological importance, Jatobá presents agronomic potential for its stem and fruit. This species has mealy pulp surrounding the seeds of the fruit, rich in nutrients and the resin exuded from the trunk is rich in terpenes making this an important species for commercial use (Dias et al. 2013). The Jatobá has medicinal properties and its different parts are used in local folk medicine as tonic, expectorant, hepatoprotective and dewormer (Bezerra et al. 2013). Previous studies have demonstrated the biological activities of Hymenae courbaril species, for example, anti-inflammatory activity (Jayaprakasam et al. 2007), while others studies have been identified and isolated compounds with antioxidant and myorelaxant activities of $H$. courbaril (Bezerra et al. 2013).

Nevertheless, there are no studies in the literature regarding the anti-melanoma and genotoxicity activity in this species. Therefore, this work brings a contribution to the knowledge of Brazilian medicinal plants, offering important information about its pharmacological effectiveness and its safe use. This study aimed to evaluate genotoxic, antigenotoxic, anti-melanoma and antioxidant activities of the hydroethanolic extract from $H$. courbaril seeds and also evaluate the presence of flavonoid compounds.

\section{MATERIALS AND METHODS}

REAGENTS

RPMI medium (Gibco Life Technologies), Cyclophosphamide (CAS n. 50-18-0; Endoxan, Baxter Oncology Gmb, German), 2,2-diphenyl-1picrylhydrazyl (DPPH) (Sigma-Aldrich Chemical Co., St Louis, MO, USA). All other chemicals and reagents used in this study were of analytical grade.

\section{PLANT MATERIAL}

The fruits of Hymenae courbaril were collected in Assis located in Southeast Brazil between November 2012 and February 2013 (H. courbaril$22^{\circ} 39^{\prime} 00.66^{\prime \prime} \mathrm{S}$ and $50^{\circ} 26^{\prime} 15.86^{\prime \prime} \mathrm{W}$, at an altitude of about $845 \mathrm{~m}$. H. courbaril have been taxonomically identified and a voucher specimen has been deposited in the Herbarium Assisense (HASSI) under number of 186 . The seeds were separated from the pulp, cleaned and dried at $40^{\circ} \mathrm{C}$ in an oven with air circulation (Cienlab, Brazil) and posteriorly grounded in a Wiley type mil (Cienlab, CE-430, Brazil).

\section{PREPARATION OF EXTRACTS}

The ground material (50 g) was macerated with hydroethanolic solution (70\% ethanol-water) (500 $\mathrm{mL}$ ) as solvent for $24 \mathrm{~h}$, at room temperature, in the dark with constant stirring. The process was repeated twice with the same powder. The resulting extracts were combined, filtered and concentrated under vacuum (Marconi, MA-120, Brazil). After this process, the hydroethanolic extracts were frozen and subsequently lyophilized (Liotop, L101, Brazil). The dried crude extract (EHC) was kept in small opaque bottle at room temperature until use.

In vitro CYTOTOXICITY ASSAY IN B16F10 MELANOMA CELLS

The cytotoxicity assay was performed using B16F10-Nex2 murine melanoma cell line. The B16F10-Nex 2 cells $\left(2 \times 10^{3}\right.$ cells $)$ were seeded into 
the wells of a 96 well plate (Corning Costar) and treated with $100 \mu \mathrm{L}$ of different concentrations of $H$. courbaril extract previously dissolved at different concentrations $(12.5,25,50,100$ and $200 \mathrm{mg} / \mathrm{mL})$ in DMSO (Dimethylsulfoxide) and RPMI such that the concentration of DMSO did not exceed $2 \%$, or DMSO $2 \%$ or Negative control (RPMI medium and B16F10-Nex2 cells), resulting in a final volume of $200 \mu \mathrm{L}$. Then, they were incubated for 24 and 48 $\mathrm{h}$ at $37^{\circ} \mathrm{C}$ in a $5 \% \mathrm{CO}_{2}$ atmosphere. Cell viability was quantified using the Trypan Blue exclusion method. All experiments were performed in triplicate. The results were expressed as percentage of cell viability.

\section{MOUSE BONE MARROW MICRONUCLEUS AND CHROMOSOMAL ABERRATION TEST}

Antigenotoxic effects of $H$. courbaril extract on cyclophosphamide-induced micronucleus in mice was tested using seven-week to twelve-week old male Swiss albino mice (Mus musculus Muridae, Rodentia) weighing 25-35 g purchased from an animal breeding center (Vallé, Uberlândia, $\mathrm{MG}$, Brazil) and acclimatized in cages at $24 \pm 1^{\circ} \mathrm{C}$ under $12 \mathrm{~h}$ light period for one week. During the acclimatization and throughout the experiments, the mice had free access to standard granulated chow and drinking water. Each cage contained five mice, which were randomly assigned to one of the 8 following groups: negative control group, given distilled water by oral gavage; positive control group, given a single intraperitoneal injection containing the equivalent of $0.2 \mathrm{mg}$ per $100 \mathrm{~g}$ of body weight (bw) of cyclophosphamide (CAS n. 50-18-0; Endoxan, Baxter Oncology $\mathrm{Gmb}$, Germany), dissolved in distilled water; the extract groups, given the equivalent of $50 \mathrm{mg}, 100$ $\mathrm{mg}$ or $200 \mathrm{mg}$ per $1000 \mathrm{~g}$ (bw) of extract each day for 7 days by oral gavage; and the experimental groups, given the same treatment as for the extract groups except that on the seventh day the mice also received the same treatment as the positive control group. The experimental protocol followed the
Ethical Principles in Animal Research adopted by the Brazilian College of Animal Experimentation and was approved by the Ethical Committee for animals use (Permit number: 002/2010). All the mice were sacrificed by cervical dislocation on day eight. This study conforms to the relevant Brazilian guidelines regarding the ethical use of living animals. Genotoxic effects were evaluated in the mouse bone marrow by the micronucleus test (Schmid 1975). Immediately after sacrificing the mice, both femurs were removed from each mouse and the bone marrow flushed out into centrifuge tubes containing $2 \mathrm{~mL}$ of fetal calf serum and 1000 revs. $\mathrm{min}^{-1}$ for $10 \mathrm{~min}$, after which the supernatant was discarded and the pellet resuspended in a drop of serum and a smear made on a clean slide. The smear was air-dried, fixed with absolute methanol for $5 \mathrm{~min}$ then air-dried and either stored at room temperature or directly stained for $5 \mathrm{~min}$ with a freshly prepared working solution of Giemsa stain diluted $1: 1 \mathrm{v} / \mathrm{v}$ in $0.06 \mathrm{M}$ sodium phosphate buffer and $0.06 \mathrm{M}$ potassium phosphate buffer (both at $\mathrm{pH}$ 6.8). After staining the slides were rinsed in distilled water, dried at room temperature and scored for micronucleus according to the criteria of Krishna and Hayashi (2000) using objective lens of $100 \mathrm{x}$ magnification and a Carl Zeiss optical microscope. 2000 polychromatic erythrocytes (PCE) per mouse were scanned and the number of micronucleated PCE (MNPCE) was recorded. To compare the frequencies of MNPCE and normal PCE between treated and control groups, the results were expressed as mean \pm standard deviation based on differences among the mice within same group. For the chromosomal aberration test it was scanned 250 metaphases and gaps, chromosome breakage, as well as rings were recorded.

\section{DPPH RADICAL SCAVENGING ACTIVITY}

The DPPH radical scavenging activity of the extracts was determined according to the technique described by Blois (1958). One $\mathrm{mL}$ of the 100 $\mathrm{mM}$ acetate buffer solution ( $\mathrm{pH}$ 5.5) were mixed with $1.25 \mathrm{~mL}$ of absolute ethanol, then, $250 \mu \mathrm{L}$ of 
$500 \mu \mathrm{M}$ DPPH solution (in ethanol) and $50 \mu \mathrm{L}$ of tested samples $(250 \mu \mathrm{g} / \mathrm{mL}$ in ethanol) or standard (gallic acid- $80 \mu \mathrm{g} / \mathrm{mL}$ in ethanol) was added. After incubation at room temperature for $30 \mathrm{~min}$, the absorbance of each sample or standard was determined at $517 \mathrm{~nm}$ in spectrophotometer UVVIS (Femto, 800XI, Brazil). All determinations were performed in triplicate. The ability to scavenge the DPPH radical was calculated using the following equation: Antioxidant activity (\%) $=[($ Acontrol-Asample $) /$ Acontrol $] \mathrm{x}$ 100, where A control is the absorbance of the control and A sample is the absorbance of the sample.

\section{TOTAL FLAVONOID CONTENT}

The total flavonoid content were measured by the colorimetric-based method assay (Christ and Mueller 1960). Briefly, $1.0 \mathrm{~mL}$ of the plant extracts was mixed with $4 \mathrm{~mL} \mathrm{70 \%} \mathrm{aqueous} \mathrm{ethanol,} \mathrm{and}$ $0.5 \mathrm{~mL} \mathrm{NaNO}_{2}(5 \% \mathrm{w} / \mathrm{v})$ was added. After $6 \mathrm{~min}$, $0.5 \mathrm{~mL} \mathrm{AlCl}_{3}(10 \% \mathrm{w} / \mathrm{v})$ and $3 \mathrm{~mL} \mathrm{NaOH}(1 \mathrm{M})$ were added, followed by the addition of distilled water to reach $10 \mathrm{~mL}$. The solution was mixed and incubated for $15 \mathrm{~min}$ at room temperature. The absorbance of the extracts was measured using a UV- spectrophotometer (Femto, 800XI, Brazil) at $510 \mathrm{~nm}$ against the control. The control contained all the reaction reagents except the sample. The flavonoid content was calculated from the calibration curve and expressed as mg of rutin equivalents per gram of dried extract (mg RE/g dry extract). Each sample was tested in triplicate.

\section{ANALYSIS OF FLAVONOIDS BY HPLC}

Aiming to identify classes of compounds that may be linked to the activities evaluated in this study, the hydroethanolic extract from seeds of $H$. courbaril was analyzed by analytical HPLC. A sample (10 $\mathrm{mg}$ ) of the hydroethanolic extract of $H$. courbaril seeds were dissolved in $1 \mathrm{~mL}$ of methanol /water $(7: 3 \mathrm{v} / \mathrm{v})$ solution and filtered through a syringe filter with PTFE membrane $(0.45 \mu \mathrm{m})$. The filtered solution was applied to a solid-phase extraction cartridge (Strata-X, Phenomenex ${ }^{\circledR}$ ) containing 500 $\mathrm{mg}$ of $\mathrm{C} 18$ silica to remove non-polar compounds and tannins.

Chromatographic separation was performed in HPLC, quaternary gradient pump PU-2089S plus Jasco ${ }^{\circledR}$, coupled photodiode array detector (PAD) with scan range 200-900 nm, MD-2015 Plus (Jasco $\left.{ }^{\circledR}\right)$, AS-2055 autosampler (Jasco $\left.{ }^{\circledR}\right)$ and CO-2060 plus column oven. The HPLC analyses were performed using a reverse phase column (Phenomenex ${ }^{\circledR}$ Luna $\mathrm{C}_{18}, 250 \times 4.6 \mathrm{~mm}$ internal diameter; $5 \mu \mathrm{m})$ and Phenomenex ${ }^{\circledR}(4 \times 3 \mathrm{~mm}$ internal diameter). The mobile phase was composed of solvent A ( $0.1 \%$ formic acid in methanol), and solvent B $(0.1 \%$ formic acid in water). The data acquisition and treatment were performed using the Jasco Chrom Pass chromatography data system (Version 1.8.1.6). The samples were monitored in PDA detector into the visible region of the spectrum (UV-Vis) in the range $200-600 \mathrm{~nm}$.

\section{STATISTICAL ANALYSIS}

The data were expressed as the mean \pm SD by measuring three independent replicates. The chromosomal aberrations were analyzed statistically using the nonparametric Mann-Whitney U-test. Antioxidant activity was realized an analysis of variance using one-way ANOVA followed by Tukey's test the significance of differences between means obtained among the treatments at the level $\alpha \leq 0.05$ of significance using the BioEstat software version 5.0 (Ayres et al. 2007).

\section{RESULTS AND DISCUSSION}

In vitro CYTOTOXICITY ASSAY IN B16F10 MELANOMA CELLS

The Figure 1 shows the comparison between the cytotoxic effects of different concentrations of hydroethanolic extract of $H$. courbaril seeds 
under cell line B16F10-Nex2 after 24 and 48 h of incubation.

One of the most important characteristics of cancer is the lack of control of the cell proliferation, differentiation and death (Loizzo et al. 2014). Therefore, compounds with antiproliferative activity becomes an important tool in combating this disease. The in vitro assay for the 24 and $48 \mathrm{~h}$ showed a marked decrease in the number of cells demonstrating that hydroethanolic extract from Hymenaea courbaril seeds has concentration and time-dependent cytotoxic effect against B16F10 melanoma cells line.

For the incubation period of 24 and 48 hour, the extract at a concentration of $50 \mu \mathrm{g} / \mathrm{mL}$ reduced the number of cells by 58 and $91 \%$, respectively, when compared to the negative control. This demonstrates that the time variation may interfere in the effect of a given concentration of the substance.

Figure 2 shows the cytotoxic activity of the extract at concentrations of $12.5,50$ and $100 \mu \mathrm{g} /$ $\mathrm{mL}$ compared to the negative control after $48 \mathrm{~h}$ exposure period, demonstrating a significant cell growth reduction.

The cytotoxicity assay is a rapid method for screening natural and synthetic products with potential antitumor (Oliveira et al. 2013), this allows to determine the concentration and the time required for the occurrence of cell death in response to treatments. Several authors have reported cytotoxic activity of plants on melanoma cells by in vitro as well as in vivo methods. Krifa et al. (2014) demonstrated in vitro and in vivo significant anticancer effect of aqueous gall extract from Limoniastrum guyonianum. Rajasekar et al. (2012) showed cytotoxic activity of Lithospermum erythrorhizon on B16F10 cells, same activity was demonstrated by Oliveira et al. (2013) evaluating the latex of Synadenium grantii.

\section{MICE BONE MARROW MICRONUCLEUS TEST AND CHROMOSOMAL ABERRATION TEST}

An important feature to be considered in studies of compounds with pharmacological applicability is

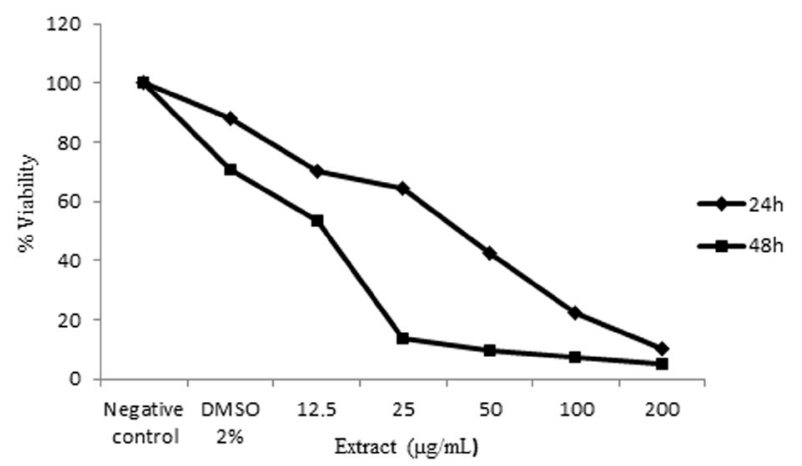

Figure 1 - Effect of $H$. courbaril extract on B16F10- Nex2 melanoma cell line using Trypan blue viability assay for 24 and $48 \mathrm{~h}$ exposure periods. The values represent the means \pm S.D.

the balance between toxic and therapeutic effects (Cariddi et al. 2012). The increased frequency of micronucleated cells acts as a biomarker of genotoxic effects (Felzenszwalb et al. 2013). Table I shows the frequency of micronuclei in polychromatic erythrocytes (MNPCE) of bone marrow in mice after administration of $H$. courbaril seed extract, alone and in combination with Cyclophosphamide. In the groups treated with extract only, there was no significant difference in the number of MNPCEs between the evaluated concentrations, but they presented a reduction in the number of MNPCEs in comparison to the negative control. For the groups treated with the extract association and Cyclophosphamide, the number of MNPCEs observed did not differ between the concentrations evaluated and also in comparison with the negative control. These results reveals that the extract of $H$. courbaril does not present genotoxic properties, besides inhibiting the genotoxicity of cyclophosphamide in bone marrow cells of mice at the evaluated concentrations.

The groups treated with different concentrations of $H$. courbaril seed extract did not showed significant differences in mitotic index when compared with each other and the negative control group, indicating that these treatments were not cytotoxic (Table II). The groups treated with extract and CP exhibited significant mitotic index reduction in comparison with the groups treated only with extract, but less 

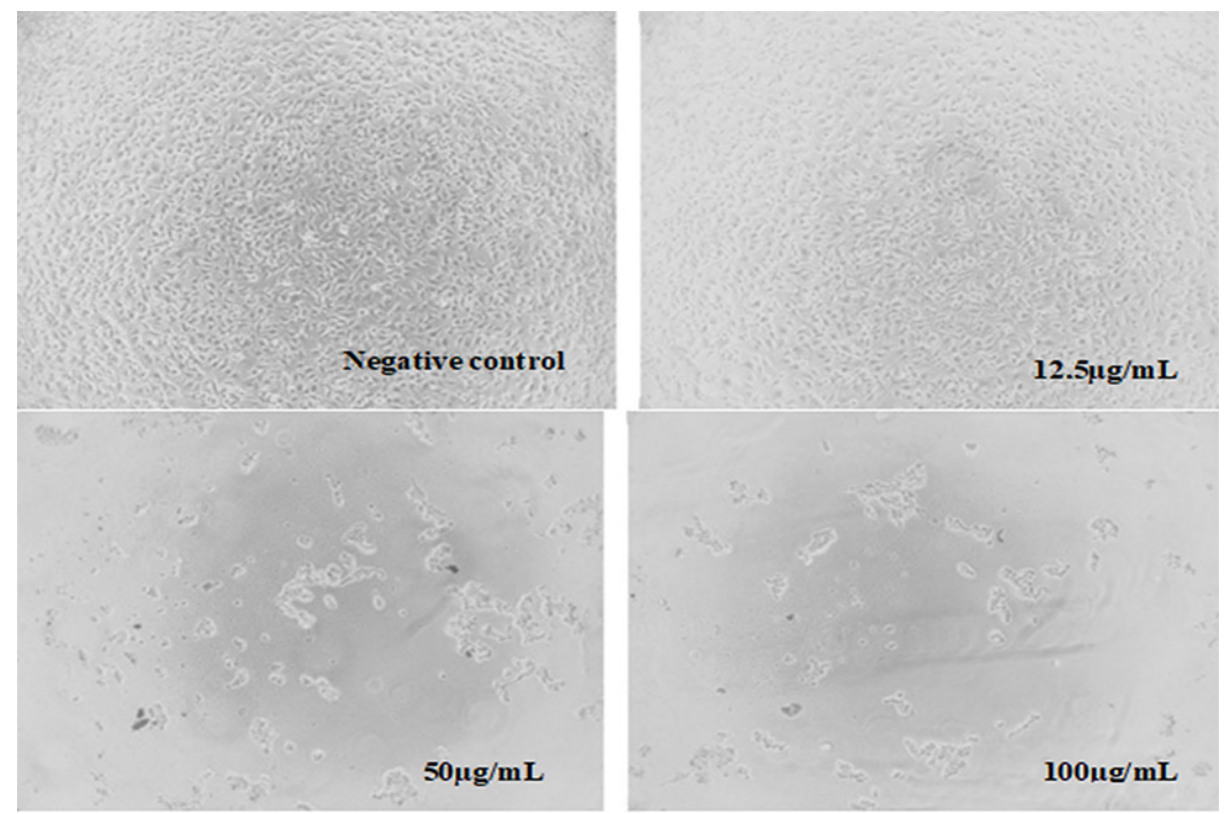

Figure 2 - Effect of $H$. courbaril extract on B16F10- Nex2 melanoma cell line for 48 h exposure period.

than the $\mathrm{CP}$ positive control. Maximum decrease in chromosomal aberrations were noticed in animals treated with E200 (4.8\%), however, chromosomal aberrations decreased correspondingly with the increasing concentration of the extract in both treatments with and without CP. Among the different types of chromosomal aberrations a larger number of breaks were observed, followed by gaps and rings. When animals were treated with E50, E100 or E200, the percentages of breaks, were dramatically reduced compared to $\mathrm{CP}$-induced aberrations.

Cyclophosphamide is a mutagenic substance that has been widely used as a positive control for genotoxicity testing (Leite-legatti et al. 2012). CP positive control in this study showed a significant induction of chromosomal damage in comparison to the negative control (distilled water), but $H$. courbaril extract was able to reduce these chromosomal damage thus demonstrating effect chemopreventive against cyclophosphamide induced damage. Several studies reported antigenotoxic activity in plant and its extracts, such as Mandevilla velutina (Silva et
TABLE I

Frequency of erythrocytes polychromatics micronucleuds (MNPCEs) of bone marrow cells of Swiss mice in experimental groups treated with hidroethanolic extract of $H$. courbaril seed.

\begin{tabular}{cccc}
\hline Treatments & $\begin{array}{c}\mathbf{N}^{\mathbf{o}} \text { of } \\
\text { animals }\end{array}$ & $\mathbf{N}^{\mathbf{0}}$ MNPCE & $\begin{array}{c}\text { MNPCE } \\
\text { Mean } \pm \text { SD (\%) }\end{array}$ \\
\hline NC & 5 & 35 & $0.35 \pm 0.09 \mathrm{a}$ \\
E50 & 5 & 09 & $0.09 \pm 0.01 \mathrm{~b}$ \\
E100 & 5 & 06 & $0.06 \pm 0.01 \mathrm{~b}$ \\
E200 & 5 & 03 & $0.03 \pm 0.03 \mathrm{~b}$ \\
E50 + CP & 5 & 50 & $0.50 \pm 0.17 \mathrm{a}$ \\
E100+CP & 5 & 34 & $0.34 \pm 0.11 \mathrm{a}$ \\
E200+CP & 5 & 22 & $0.22 \pm 0.03 \mathrm{a}$ \\
CP & 5 & 286 & $2.86 \pm 1.78 \mathrm{c}$ \\
\hline
\end{tabular}

$\mathrm{NC}=$ Negative Control was distilled water; Animals were treated with the following doses of extract: E50: $50 \mathrm{mg} / \mathrm{kg}$ bw, E100: $100 \mathrm{mg} / \mathrm{kg}$ bw, E200: 200mg/kg bw, E50+CP: 50mg/ $\mathrm{kg} \mathrm{bw}+2 \mathrm{mg} / \mathrm{kg}$ bw of cyclophosphamide (CP), E100+CP: $100 \mathrm{mg} / \mathrm{kg}$ bw $+2 \mathrm{mg} / \mathrm{kg}$ bw of cyclophosphamide (CP), E200+CP: $200 \mathrm{mg} / \mathrm{kg}$ bw $+2 \mathrm{mg} / \mathrm{kg}$ bw of cyclophosphamide (CP), CP: $2 \mathrm{mg} / \mathrm{kg}$ bw of cyclophosphamide. Same letters within the same column indicate no significant diferences among samples by Tukey test $(\alpha \leq 0.05)$. ${ }^{*}$ They were analyzed 2000 erythrocytes polychromatics (EPC) for each experimental and control group. 
TABLE II

Number and mean percentages of chromosomal aberrations and mean number of mitotic index in mice bone-marrow cells after treatment of the hidroethanolic extract of $H$.courbaril seed with or without $C P$. They were analyzed 2000 erythrocytes polychromatics (EPC) for each experimental and control group.

\begin{tabular}{|c|c|c|c|c|c|c|}
\hline \multirow[t]{2}{*}{ Treatments } & \multirow{2}{*}{$\begin{array}{c}\text { Mitotic index } \\
(\operatorname{mean} \pm \text { SD })\end{array}$} & \multicolumn{3}{|c|}{ Different types of chromosomal aberrations } & \multicolumn{2}{|c|}{$\begin{array}{l}\text { Number of cells } \\
\text { with aberrations }\end{array}$} \\
\hline & & Breaks & Gap & Rings & Total & $\operatorname{Mean} \pm \operatorname{SD}(\%)$ \\
\hline $\mathrm{NC}$ & $1.38 \pm 0.52 \mathrm{a}$ & 24 & 6 & 0 & 30 & $12.0 \pm 3.74 \mathrm{a}$ \\
\hline E50 & $1.58 \pm 0.61 \mathrm{a}$ & 22 & 4 & 0 & 26 & $10.4 \pm 2.53 \mathrm{a}$ \\
\hline $\mathrm{E} 100$ & $1.42 \pm 0.45 \mathrm{a}$ & 18 & 2 & 0 & 20 & $8.0 \pm 1.09 \mathrm{a}$ \\
\hline E200 & $1.32 \pm 0.56 \mathrm{a}$ & 11 & 1 & 0 & 12 & $4.8 \pm 0.98 b$ \\
\hline $\mathrm{E} 50+\mathrm{CP}$ & $0.93 \pm 0.34 b$ & 34 & 4 & 1 & 39 & $15.6 \pm 1.17 \mathrm{c}$ \\
\hline $\mathrm{E} 100+\mathrm{CP}$ & $1.08 \pm 0.27 \mathrm{~b}$ & 21 & 5 & 2 & 28 & $11.2 \pm 0.97 \mathrm{a}$ \\
\hline $\mathrm{E} 200+\mathrm{CP}$ & $1.12 \pm 0.32 \mathrm{~b}$ & 17 & 3 & 1 & 21 & $8.40 \pm 1.02 \mathrm{a}$ \\
\hline $\mathrm{CP}$ & $0.47 \pm 0.21 \mathrm{c}$ & 121 & 26 & 8 & 155 & $62.0 \pm 11.22 \mathrm{~d}$ \\
\hline
\end{tabular}

$\mathrm{NC}=$ Negative Control was distilled water. Animals were treated with the following doses of extract: E50: $50 \mathrm{mg} / \mathrm{kg}$ bw, E100: $100 \mathrm{mg} / \mathrm{kg}$ bw, E200: $200 \mathrm{mg} / \mathrm{kg}$ bw, E50+CP: $50 \mathrm{mg} / \mathrm{kg}$ bw $+2 \mathrm{mg} / \mathrm{kg}$ bw of cyclophosphamide (CP), E100+CP: $100 \mathrm{mg} / \mathrm{kg}$ bw $+2 \mathrm{mg} / \mathrm{kg}$ bw of cyclophosphamide (CP), E200+CP: $200 \mathrm{mg} / \mathrm{kg}$ bw $+2 \mathrm{mg} / \mathrm{kg}$ bw of cyclophosphamide (CP), CP: $2 \mathrm{mg} / \mathrm{kg}$ bw of cyclophosphamide. Same letters within the same column indicate no significant diferences among samples by Tukey test ( $\alpha \leq 0.05)$.

al. 2008), Azadirachta indica (Vinod et al. 2011) and Liquidambar orientalis Mill. var. orientalis (Saraç and Sen 2014). The results of the present study suggest that extract from $H$. courbaril seeds does not produces bone marrow micronucleus or chromosomal aberration, and thus, might be considered a source of antigenotoxic compounds.

\section{DPPH RADICAL SCAVENGING ACTIVITY}

Free radical-scavenging capacity of the hydroethanolic extract from $H$. courbaril seeds, measured by DPPH assay are shown in Table III.

Reactive oxygen species contribute to cancer development and progression by increasing DNA mutations, DNA damage and cell proliferation (Reuter et al. 2010). The antioxidants act as protective mechanisms which are able to donate electron and neutralize the reactive oxygen species (Saeidnia and Abdollahi 2013). DPPH assay is an easy, rapid and inexpensive colorimetric method for the evaluation of antioxidant properties; it is commonly used to measure the antioxidant content of several vegetables in different solvent systems (Loizzo et al. 2014).
The antioxidant capacity of the seed extract from $H$. courbaril $(78.94 \%)$ did not significantly differ from gallic acid standard (79.98\%). This data support previous studies such as Dias et al. (2013) who evaluated the seed oil of $H$. courbaril and found antioxidant capacity of $83.49 \%$ and Bezerra et al. (2013) who reported antioxidant activity in extracts and fractions from stembark of Hymenaea courbaril L.

\section{TOTAL FLAVONOID CONTENT}

The result of flavonoids observed to this extract (442.25 mg RE/g of dry extract) suggests that this class of compounds is responsible for significant antioxidant activity observed in the extract, this is due to its structure formed by the phenolic aromatic rings attached to one or more hydroxyl groups, which makes them capable of binding to free radicals (Saraç and Ben 2014).

Flavonoids possess a wide spectrum of pharmacological activities. Among these, the anticancer activity is highlighted. Therefore, different types of flavonoids and their mechanisms of action have been investigated in the search 
TABLE III

DPPH radical scavenging activity and total flavonoids content (TFc) of the hidroethanolic extract of Hymenaea courbaril seed (HEHCS).

\begin{tabular}{|c|c|c|}
\hline Sample & $\begin{array}{c}\% \text { Antioxidant } \\
\text { activity }\end{array}$ & $\begin{array}{c}\text { TFc } \\
(\mathrm{mg} * \mathrm{RE} / \mathrm{g} \text { of dry extract) }\end{array}$ \\
\hline HEHCS $(250 \mu \mathrm{g} / \mathrm{mL})$ & $78.94 \pm 0.46 \mathrm{a}$ & $442.25 \pm 18.03$ \\
\hline Gallic acid $(80 \mu \mathrm{g} / \mathrm{mL})$ & $79.98 \pm 1.60 \mathrm{a}$ & \\
\hline
\end{tabular}

*RE=Routine Equivalent. Same letters within the same column indicate no significant diferences among samples by Tukey test $(\alpha \leq 0.05)$.

for natural source substances with potential application in different therapies for various diseases (Ravishankar et al. 2013). The results of this study demonstrate the potential of this species as a source of flavonoid. Furthermore, there are few scientific studies investigating or demonstrating the flavonoid content of extracts and preparations from species of the genus Hymenaea.

\section{ANALYSIS OF FLAVONOIDS BY HPLC}

Chromatogram of the hydroethanolic extract from $H$. courbaril seeds obtained by HPLC-PAD showed four major peaks (Figure 3). Flavonoid compounds have a characteristic absorption spectrum in the UV region with two bands of higher absorption, which the band I absorbs between 300-400 nm and refers to ring $\mathrm{B}$ and the band II absorbs between 240-285 $\mathrm{nm}$ and refers to ring A.

HPLC-PAD chromatogram obtained from the hydroethanolic extract of $H$. courbaril seeds in analytical scale revealed the presence of flavonoid compounds. Peaks were eluted between 19.36 and 30.15 minutes, the peak 4 eluted at around 30.15 minutes is highlighted due to the higher intensity (at $350 \mathrm{~nm}$ ) compared to the other peaks (Figure 4).

The UV spectra of all numbered peaks showed absorption between $284-350 \mathrm{~nm}$ relating to band I and therefore, suggests that the peaks of the chromatogram refer to flavones. The flavone band I occur at 304-350 nm (Almeida et al. 2012).

The data obtained from the HPLC-PAD analysis support previous studies with other species of this genus. c. Maranhão et al. (2013) identified

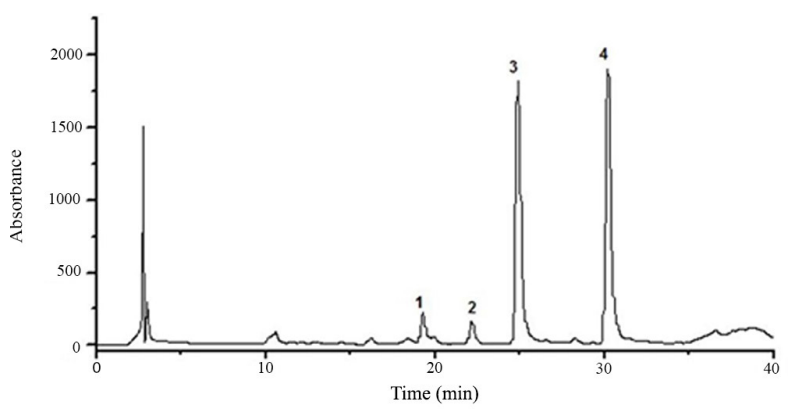

Figure 3 - HPLC-PAD flavonoids profile of the hydroethanolic extract from seeds of $H$. courbaril. Phenomenex ${ }^{\circledR}$ Luna Column (C18 $250 \times 4.6 \mathrm{~mm}$ d. i., $5 \mu \mathrm{m})$. Eluent A $(0.1 \%$ formicacid in methanol); Eluent $\mathrm{B}(0.1 \%$ formic acid in water). Ranging from $20-50 \%$ of $\mathrm{A}$ in $30 \mathrm{~min}$ and $30-35 \%$ of $\mathrm{A}$ in $5 \mathrm{~min}$ at a flow rate of $1 \mathrm{~mL} \cdot \mathrm{min}^{-1}$. Injection volume: $40 \mu \mathrm{L}$. Column Oven: $40^{\circ} \mathrm{C} . \lambda=350 \mathrm{~nm}$.

a flavonone (hultenin) and other three flavonoids (taxifolin, quercetin and 7-methoxycatechin) in extract of heartwood of $H$. stigonocarpa, Dimech et al. (2013) reported presence of flavonoids in extracts of this same species.

\section{CONCLUSION}

The in vitro cytotoxic activity and in vivo genotoxic and antigenotoxic activities of the extract of $H$. courbaril seeds on murine melanoma cells was first time reported in this paper. The results obtained in this study exposed that Hymenaea courbaril has cytotoxic effect against B16F10 melanoma cells line, antigenotoxic effect on mice bone marrow cells and present antioxidant activity. Furthermore, the results obtained in this study exihibited that Hymenaea courbaril has flavonoids which possibly belong to the class of flavones. This can explain the biological activities observed in this study. 

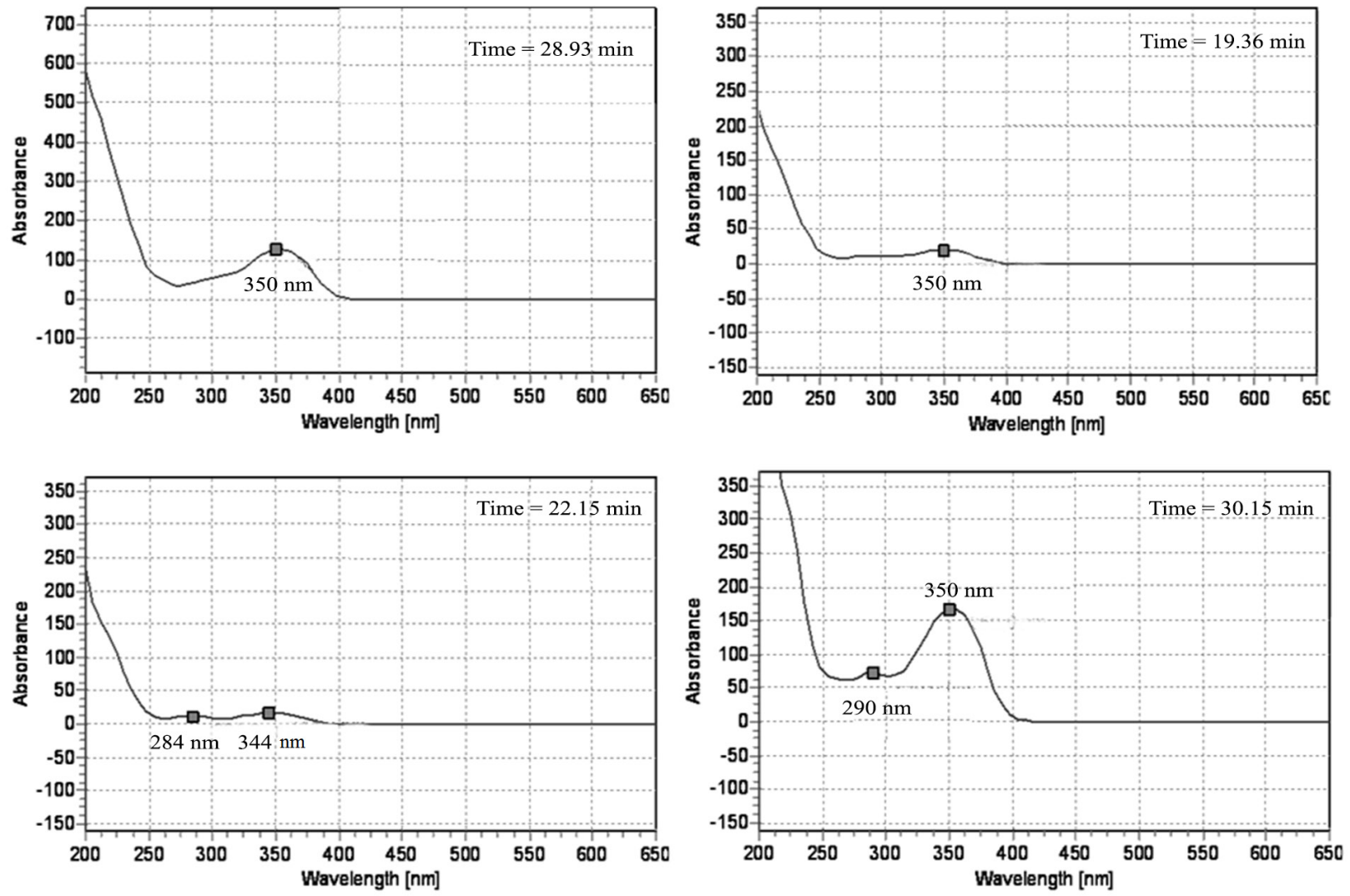

Figure 4 - Spectra in the UV-Vis region obtained by HPLC-PAD of the hydroethanolic extract from seeds of H. courbaril.

\section{ACKNOWLEDGMENTS}

This work was supported by Fundação de Amparo à Pesquisa do Estado de São Paulo through a grant (FAPESP: 2011/15430-5).

\section{AUTHOR CONTRIBUTIONS}

The authors Kamille Daleck Spera and Pamela Cristina e Santos contributed to concept, design and experimental studies of antioxidant activity, Patrícia Aparecida Figueiredo contributed to concept, design and experimental studies of genotoxicity activity. Fernando Cesar Barbosa, Caio Pismel Alves and Carlos Rogério Figueiredo contributed to experimental studies of antimelanoma activity and statistical analysis. Anne Lígia Dokkedal and Luiz Leonardo Saldanha contributed to phytochemical analysis, Paulo Cesar Ferreira, Luciana Pereira Silva and Regildo Marcio
Gonçalves da Silva contributed to concept, design, experimental studies data acquisition, statistical analysis and manuscript review.

\section{REFERENCES}

ALMEIDA JRGS, SILVA MEGC, GUIMARÃES AL, OLIVEIRA AP, ARAÚJO CS, FILHO JAS, FONTANA AP, DAMASCENO PKF, BRANCO CRC AND BRANCO A. 2012. HPLC-DAD analysis and antioxidant activity of Hymenaea martiana Hayne (Fabaceae). J Chem Pharm Res 4(2): 1160-1166.

ASSAF AM, HADDADIN RN, ALDOURI NA, ALABBASSI R, MASHALLAH S, MOHAMMAD M AND BUSTANJI Y. 2013. Anticancer, anti-inflammatory and anti-microbial activities of plant extracts used against hematological tumors in traditional medicine of Jordan. J Ethnopharmacol 145(1): 728-736.

AYRES M, AYRES JRM, AYRES DL AND SANTOS AA. 2007. BIOESTAT - Aplicações estatísticas nas áreas das ciências biomédicas. Ong Mamiraua. Belém, PA. Volume único, $364 \mathrm{p}$.

BEZERRA GP, GÓIS RWDS, BRITO TS, LIMA FJB, BANDEIRA MAM, ROMERO NR, MAGALHÃES PJC 
AND SANTIAGO GMP. 2013. Phytochemical study guided by the myorelaxant activity of the crude extract, fractions and constituent from stem bark of Hymenaea courbaril L. J Ethnopharmacol 149(1): 62-69.

BLOIS MS. 1958. Antioxidant determinations by the use of a stable free radical. Nature 181: 1199-1200.

CARIDDI L, ESCOBAR F, SABINI C, TORRES C, REINOSO E, CRISTOFOLINI A, COMINI L, MONTOYA SN AND SABINI L. 2012. Apoptosis and mutagenicity induction by a characterized aqueous extract of Baccharis articulata (Lam.) Pers. (Asteraceae) on normal cells. Food Chem Toxicol 50(1): 155-161.

CHOUDHARI SK, CHAUDHARY M, GADBAIL AR, SHARMA A AND TEKADE S. 2014. Oxidative and antioxidative mechanisms in oral cancer and precancer: A review. Oral Oncol 50(1): 10-18.

CHRIST B AND MUELLER KH. 1960. On the serial determination of the content of flavonol derivatives in drugs. Archiv der Pharmazie. 293(12): 1033-1042.

DIAS LS, LUZIA DMM AND JORGE N. 2013. Physicochemical and bioactive properties of Hymenaea courbaril L. pulp and seed lipid fraction. Ind Crops Prod 49: 610-618.

DIMECH GS, SOARES LAL, FERREIRA MA, OLIVEIRA AGV, CARVALHO MC AND XIMENES EA. 2013. Phytochemical and Antibacterial Investigations of the extracts and fractions from the stem bark of Hymenaea stigonocarpa Mart. ex hayne and effect on ultrastructure of Staphylococcus aureus induced by hydroalcoholic extract. Sci World J 1: 1-8.

FELZENSZWALB I, MARQUES MRC, MAZZEI JL AND AIUB CAF. 2013. Toxicological evaluation of Euterpe edulis: A potential superfruit to be considered. Food Chem Toxicol 58: 536-544.

JAYAPRAKASAM B, ALEXANDER-LINDO RL, DEWITT D AND NAIR MG. 2007. Terpenoids from Stinking toe (Hymeneae courbaril) fruits with cyclooxygenase and lipid peroxidation inhibitory activities. Food Chem 105(2): 485-490.

KRIFA M, SKANDRANIA I, PIZZIB A, NASRA N, GHEDIRA Z, MUSTAPHA N, GHEDIRA K AND CHEKIR-GHEDIRAA L. 2014. An aqueous extract of Limoniastrum guyonianum gall induces anti-tumor effects in melanoma-injected mice via modulation of the immune response. Food Chem Toxicol 69: 76-85.

KRISHNA G AND HAYASHI M. 2000. In vivo rodent micronucleus assay: protocol, conduct and data interpretation. Mutat Res 455(1-2) 155-166.

KRISHNAIAH D, SARBATLY R AND NITHYANANDAM R. 2011. A review of the antioxidant potential of medicinal plant species. Food Bioprod Process 89: 217-233.

KRYSTON TB, GEORGIEV AB, PISSIS P AND GEORGAKILAS AG. 2011. Role of oxidative stress and DNA damage in human carcinogenesis. Mutat Res 711: 193-201.
LEITE-LEGATTI AV ET AL. 2012. Jaboticaba peel: Antioxidant compounds, antiproliferative and antimutagenic activities. Food Res Int 49(1): 596-603.

LOIZZO MR, RASHED K, SAID A, BONESI M, MENICHINI F AND TUNDIS R. 2014. Antiproliferative and antioxidante properties of Alhagim aurorum Boiss (Leguminosae) aerial parts. Ind Crops Prod 53: 289-295.

MARANHÃO CA, PINHEIRO IO, SANTANA ALBD, OLIVEIRA LS, NASCIMENTO MS AND BIEBER LW. 2013. Antitermitic and antioxidant activities of heartwood extracts and main flavonoids of Hymenaea stigonocarpa Mart. Int Biodeterior Biodegradation 79: 9-13.

OLIVEIRA TL, MUNHOZ AC, LEMES BM, MINOZZO BR, NEPEL A, BARISON A, FÁVERO GM, CAMPAGNOLI EB AND BELTRAME FL. 2013. Antitumoural effect of Synadenium grantii Hook f. (Euphorbiaceae) latex. J Ethnopharmacol 150: 263-269.

RAJASEKAR KV, CAMPBELL LJ, NIETLISPACH D, OWEN D AND MOTT HR. 2012. ${ }^{1} \mathrm{H},{ }^{13} \mathrm{C}$ and ${ }^{15} \mathrm{~N}$ resonance assignments of the GTPase-activating (GAP) and Ral binding domains (GBD) of RLIP76 (RalBP1). Biomol NMR Assign 6(2): 119-122.

RAVISHANKAR D, RAJORAAK, GRECO F AND OSBORN HM. 2013. Flavonoids as prospective compounds for anticancer therapy. Int J Biochem Cell Biol 45(12): 28212831.

REUTER S, GUPTA SC, CHATURVEDI MM AND AGGARWAL BB. 2010. Oxidative stress, inflammation, and cancer: How are they linked? Free Radic Biol Med 49(11): 1603-1616.

SAEIDNIA S AND ABDOLLAHI M. 2013. Antioxidants: Friends or foe in prevention or treatment of cancer: The debate of the century. Toxicol Appl Pharmacol 271(1): 49-63.

SARAÇ N AND ŞEN B. 2014. Antioxidant, mutagenic, antimutagenic activities, and phenolic compounds of Liquidambar orientalis Mill.Var. orientalis. Ind Crops Prod 53: 60-64.

SCHMID W. 1975. The micronucleus test. Mutat Res 31(1): 9-15.

SILVA RMG, SOUSA NC, GRAF U AND SPANÓ MA. 2008. Antigenotoxic effects of Mandevilla velutina (Gentianales, Apocynaceae) crude extract on cyclophosphamide-induced micronuclei in Swiss mice and urethane-induced somatic mutation and recombination in Drosophila melanogaster. Genet Mol Biol 31(3): 751-758.

VEGGI PC, PRADO JM, BATAGLION GA, EBERLIN MN AND MEIRELES MAA. 2014. Obtaining phenolic compounds from jatoba (Hymenaea courbaril L.) bark by supercritical fluid extraction. J Supercrit Fluids 89: 68-77.

VINOD V, TIWARI PK AND MESHRAM GP. 2011. Evaluation of mutagenic and antimutagenic activities of neem (Azadirachtaindica) seed oil in the in vitro Ames Salmonella/microsome assay and in vivo mouse bone marrow micronucleus test. J Ethnopharmacol 134(3): 931937. 